\title{
Diversity of fruit trees in the palm grove of the Ouargla region (Algeria): case of the traditional perimeters
}

\author{
Salhi Sara, Babahani Souad, Danone Dalal \& Hamdi Fatima Zohra \\ Laboratory of Saharan Bioresources, University of Kasdi Merbah Ouargla, Algeria. \\ Corresponding author, e-mail: salhi.sara@yahoo.com
}

\begin{abstract}
The present work aims to identify the biodiversity of fruit tree species in the region of Ouargla (Algeria) and to analyze the distribution of local cultivars and introduced varieties. The method adopted is to carry out surveys in the stations in the region of Ouargla Ksar Ouargla, Rouissat, N'Goussa and Hassi Ben Abdallah. The region of Ouargla seems to be the richest in fruit species with a biodiversity of 12 species. The pomegranate is present with a frequency of $29 \%$ in the traditional sector of the stations studied. The average values of the index of Shannon-W, for the study area are very low, they are estimated at 0.88 bits in the traditional sector. The average equitability is equal to 0.77 in the traditional farms. The regularity is high and the numbers of species present tend to be in equilibrium. Local cultivars, from this region, are found for pomegranate and fig. Many species are rare and are found in a few farms. The edapho-climatic conditions of the region and the salinity of the water and soil seem to be the limiting factors for this crop in the region. The preservation of this biodiversity, especially the local cultivars, as well as the implementation of a selection program and possibly of crossbreeding seem to be essential to promote the culture of fruit trees in the region of Ouargla.
\end{abstract}

KEY WORDS Biodiversity; fruit trees; local cultivars; ecological indices; Ouargla.

Received 26.08.2021; accepted 16.11.2021; published online 30.12.2021

\section{INTRODUCTION}

For a long time, man has been interested in taking care of his fruit trees, because in the orchard, found his food, a place of recreation and relaxation, but today with economic development, the fruit sector has taken another direction and is an important industrial interest in the countries.

Algeria conceals an invaluable heritage in terms of agrodiversity (Chaouia et al., 2003) whose arboriculture is very diversified. It is essentially constituted of the olive tree, the fig tree, the vine, and the citrus fruits, which are the most important species on the economic and social level. (INRAA/June 2006).

The plant genetic resources of cultivated species is one of the fundamental elements of the sustainability of oases and it is an important natural bulwark to different factors of degradation of the oasis ecosystem (Tirichine et al., 2011).

According to PAM (2007), this plant material is a cultural heritage, the historical mark of the peasant activity, distinctive testimony of a society, a land and an era. It is the object of exchange and sharing between communities, a place of memory and an intergenerational link. Its availability and its adaptation to diversified agrarian systems are, for the vast majority of farmers, guarantees of their food security.

Genetic erosion is affecting a large part of the species used in agriculture, among which a large number of local fruit tree varieties are in danger of disappearing (Chaouia et al., 2003).

In the Saharan regions and particularly in the region of Ouargla, we note the extent of abandoned agricultural land (Benbrahim, 2009). 
The wilaya of Ouargla has a cultivated area of fruit species of about 9263.56 ha (DSA, 2011, 2015). The wilaya is known as a phoenicultural area, between the palm trees, often feet of fruit trees are associated. Studies on fruit growing in this area are very rare.

The wilaya is also rich in local endemic species such as the pomegranate and the fig tree.

Our work was carried out in the wilaya of Ouargla, in six stations (Ksar, Sidi Khuiled, Hassi Ben Abdellah, Rouissat, N'Goussa and Ain Beida). It aims to analyze the distribution of local varieties of fruit trees and cultivars introduced.

It is a contribution to the evaluation of an ancestral heritage, rich and highly diversified and yet almost unknown and very little studied. This approach is part of a general framework for the preservation, conservation and development of plant genetic resources related to agriculture and food for sustainable agriculture (Khemies, 2013).

\section{MATERIAL AND METHODS}

\section{Study area}

The wilaya of Ouargla is located in the SouthEast of Algeria (Fig. 1), under the coordinates of $31^{\circ} 57^{\prime} \mathrm{N}, 5^{\circ} 19^{\prime} \mathrm{E}$. The city of Ouargla is located at an altitude of $157 \mathrm{~m}$. The wilaya of Ouargla covers an area of $163230 \mathrm{~km}^{2}$ (Rouvillois-Brigol, 1975).

In the absence of any references on the biodiversity of fruit trees in the region of Ouargla, the choice of study stations was based on information and statistics from the Directorate of Agricultural Services (DSA) and the Chamber of Agriculture of the region of Ouargla for 10 years (2005-2015).

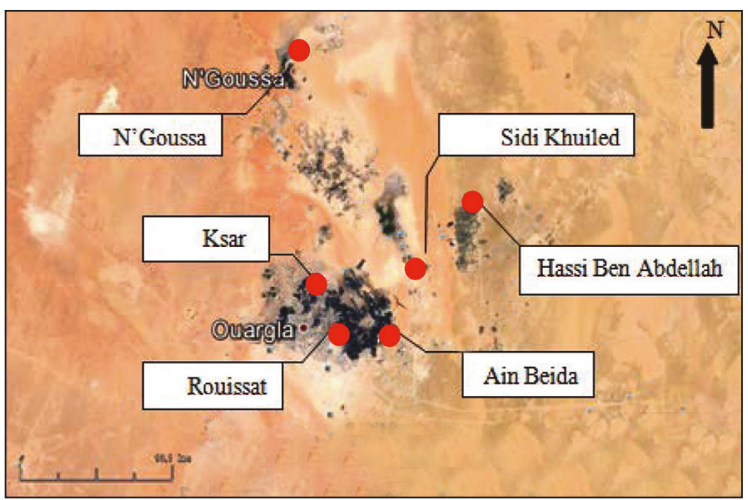

Figure 1. Location of selected stations

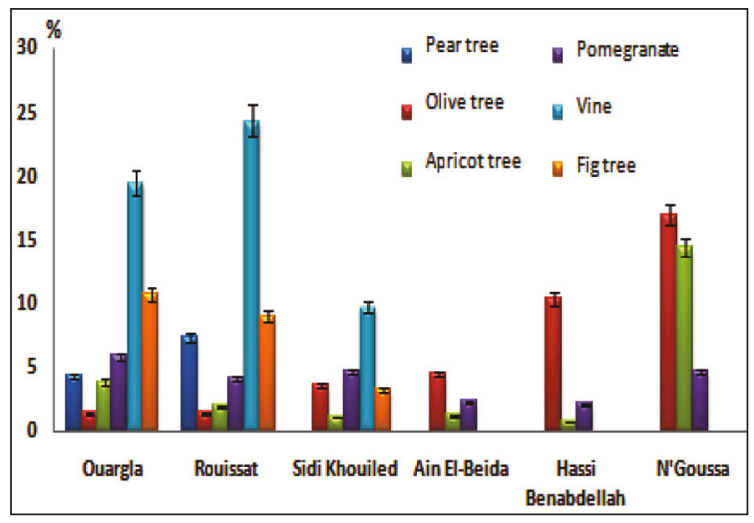

Figure 2. Percent occupancy of species in 2015 (DSA, 2015).

Figure 2 shows that the communes Hassi Ben Abdellah, N'Goussa, Ksar and Rouissat are the most cultivated in fruit trees, and that the most dominant species are: pomegranate, fig, olive and apricot.

\section{Sampling method}

The sampling consists in choosing elements in order to obtain objective information and of a measurable precision on the whole (Gounot, 1969).

We adapted subjective sampling to our study. According to Gounot (1969), the subjective sampling is the simplest method which consists in choosing the location of surveys in an intuitive way in the zones which seem to him sufficiently homogeneous and representative of the plant formation.

Following this sampling method, we conducted the surveys and sampling in 10 palmerais in each commune.

In each of these palm groves, we sampled three regular and equivalent surveys (quadras) of $81 \mathrm{~m}^{2}$ $(9 \times 9)$. This area was taken according to the most adopted spacing for the plantation of palms (Munier, 1973).

\section{Data analysis}

In the present study, the results obtained are exploited by ecological indices of composition and structure.

Ecological indices of composition:

- Total and average richness, applied to the identified species.

- Centesimal frequency, applied to the recorded fruit tree species. 
Ecological indices of structure:

- Shannon-weaver index.

- Index of heterogeneity of Simpson (1949).

- Index of equipartition, applied to the species surveyed.

\section{RESULTS AND DISCUSSION}

The species of fruit trees constitute the second vegetation stage before the date palm. The results of the inventory show that the region of Ouargla contains a significant specific diversity, estimated at 8 species, divided into six families (Fig. 3, Table 1).

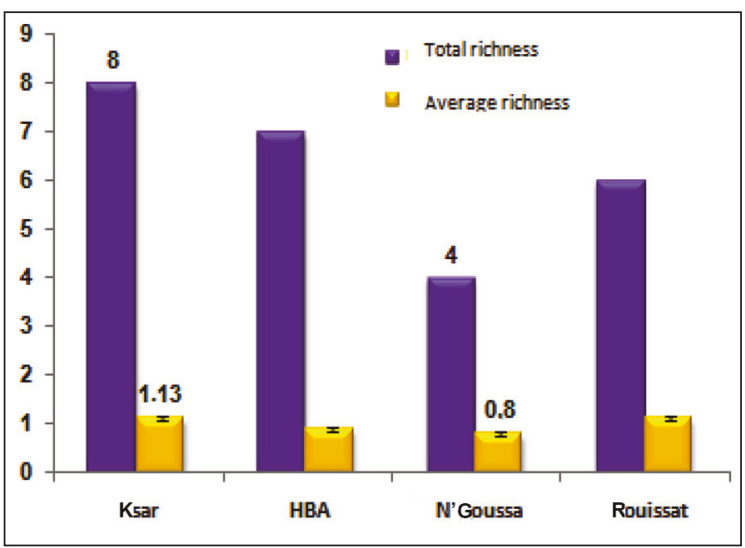

Figure 3. Total and average richness of fruit tree species, recorded in the farms of the study stations.
We have:

the family Rosaceae, represented by 1 species, such as the Apricot, Prunus armeniaca L.;

the family Moraceae, represented by 2 species, such as the Fig tree: Ficus carica L. and the Mulberry, Morus sp.;

the family Rutaceae, represented by 2 species, such as the Orange tree: Citrus sinensis L. and the Lemon tree, Citrus limon L.;

the family Lythraceae represented by only 1 species such as the Pomegranate: Punica granatum L.;

the family Vitaceae represented by one species is the Vine, Vitis vinifera L.;

the family of Oleaceae with the Olive tree, Olea europaea L.

From our results and Fig. 4, we notice, if we divide the fruit trees distributed in the study region as a percentage, the pomegranate occupies the first place with a frequency of $29 \%$ contrary to the orange tree with a frequency of $1 \%$, in the traditional palm groves.

The pomegranate tree is adapted to very varied soils, with a preference for deep alluvial or clayeysilt soils with high water retention. It does not fear active limestone. The olive tree adapts to different soils, provided that they are fresh, without excess moisture (Khemies, 2013).

The olive tree is also used as windbreaks, in the majority of the exploitations of development.

\begin{tabular}{|c|c|c|c|c|}
\hline Families & Scientific name & $\begin{array}{c}\text { Vernacular } \\
\text { name }\end{array}$ & $\begin{array}{c}\text { Arabic } \\
\text { name }\end{array}$ & Local name \\
\hline Lythraceae & Punica granatum L. & $\begin{array}{c}\text { Pomegranate } \\
\text { tree }\end{array}$ & رمان & رمان \\
\hline \multirow[t]{2}{*}{ Moraceae } & Ficus carica L. & Fig tree & تين & كرموس- كرمة \\
\hline & Morus sp. & Wall tree & 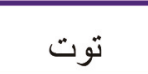 & توت \\
\hline Rosaceae & Prunus armeniaca $\mathrm{L}$. & Apricot tree & مشمش & مشماش \\
\hline \multirow[t]{2}{*}{ Rutaceae } & Citrus limon $\mathrm{L}$. & Lemon tree & ل ليمون & قارص \\
\hline & Citrus sinensis L. & Orange tree & برتقال & تشينة \\
\hline Vitaceae & Vitis vinifera $\mathrm{L}$. & Vine & عنب & عنب \\
\hline Oleaceae & Olea europaea L. & Olive tree & زيتون & زيتون \\
\hline
\end{tabular}

Table 1. Fruit trees identified in the study stations of the Ouargla region. 


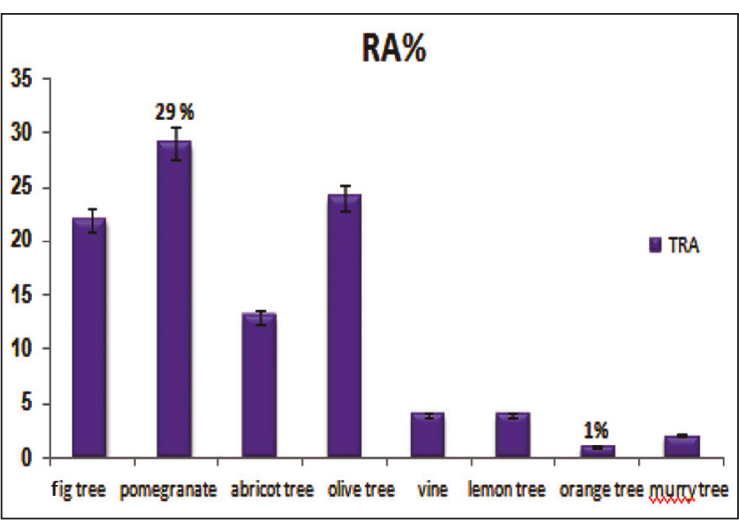

Figure 4. The centesimal frequencies of fruit species in the region of Ouargla.

The other species, medlar, orange, lemon and mulberry, seem to be introduced species in most cases. They are rare.

The values of diversity of Shannon-Weaver of the study region in the traditional farms are very weak (Fig. 5).

On the other hand that the value of equitability in the traditional sector approaches 1.

We note that the olive tree, fig tree and pomegranate are not sensitive to mild winter, but the apricot tree, peach tree, plum tree, apple tree and pear tree have very different requirements to the winter cold depending on the varieties (Khemies, 2013).

In addition, most of the traditional farms in the region of Ouargla are abandoned and abandoned due to several causes such as family confits (inheritance), lack of manpower, water, organic fertilizer, etc. (Khemies, 2013)

According to our research and the questionnaires asked to the farmers, we have identified two local cultivars: the pomegranate and the fig tree, where we found them in the 9 traditional palm groves surveyed in the Ksar, also in 9 traditional palm groves of N'Goussa.

In the Ksar station, the pomegranate tree is composed of two cultivars generally from locally grown populations and often selected more or less empirically by farmers. But these cultivars are not subject to any characterization study for identification. We have the cultivars "Hlou-ahmer" which means sweet taste and red color, the cultivar "Hamed-Abiad", local name "Armoun Assemam", which means acid taste and white color, and the cultivar "Mouz" which means intermediate taste.

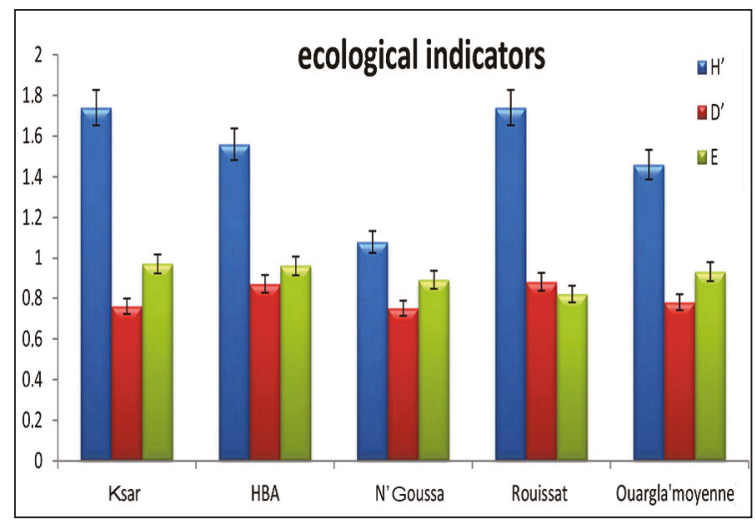

Figure 5. Ecological indices of biodiversity and equitability in the Ouargla region. H': Shannon diversity index, D': Simpson diversity index, E: equitability, TRA: traditional perimeter.

Allam (2015) also noted the presence of the same cultivars, in the pomegranate, in the region of Touggourt.

For the Fig. 3, we recorded two cultivars "takhrit", which means in Ouargli language the period of ripening in autumn, and "tasifit", which means the ripening in summer.

Allam \& Cheloufi (2013) reported the presence of the fig tree "kharfi", from the Arabic word "khrif" which means maturation in autumn and "bakor" which means early.

This parameter identifies the relationship between agricultural diversity and the cultural life of the oasis populations. It allows to know if the different local varieties are part of local customs, religious or folkloric festivities, literature, etc.

In the case of our study, fruit trees do not have such types of uses. This could be an indication of the loss of this genetic diversity, because according to Ezaguire (Eyzaguirre, 2005), the variety is preserved despite the evolution of market forces and it is given a special place in the cultural system when it has value and ritual use.

\section{CONCLUSIONS}

This study, carried out in the region of Ouargla and covering four stations (Hassi Ben Abdellah, N'Goussa, Ksar and Rouissat), is based on the study of the diversity of fruit trees.

Following the surveys conducted and sampling, we conducted other surveys in quadras to try to assess the diversity in its agricultural stations. The 
results obtained show that the richness of the stations studied in the region of Ouargla is 8 in the traditional perimeter, it remains low compared to other regions of southern Algeria such as that of el Goléa and Ghardaia.

The pomegranate occupies the first place, with a frequency of $29 \%$ in this traditional sector.

The diversity index is also low, it is marked by 0.88 bits in the traditional palm farms.

However, the equitability is 0.77 . The numbers of species present tend to be in balance with each other.

Local cultivars in this region are noted mainly for pomegranate and fig. Other species are rare and found in a few farms.

The lack of some species, in the study area, may be due to: either their poor adaptation to the edapho-climatic conditions of the region, including temperature and salinity of water and soil, as well as the lifestyle of the Ouargli population, or to the disinterest of farmers to these species in relation to the main crop which is the date palm.

\section{REFERENCES}

Bouzaher A., 1990. Technical note: Création d'oasis en Algérie. Revue Options méditerranéennes, CIHEAM, Série A, 11: 325-328.

Chaouia C., Mimouni M., Trabelsi S., Benrebiha F.Z., Boutekrabt T.-F. \& Bouchenak F., 2003. The fruit, wine and phoeniculture species. In: Abdelguerfi A. \& Ramdanes.A., Assessment of capacity building needs for the conservation and sustainable use of biodiversity important for agriculture. Recueil des communications, Atelier n॰3 du 22-23/01/2003, Alger "biodiversité importante pour l'agriculture MATE-GEF/ PNUD” Projet ALG/97/G31, pp. 19-28.

DSA of Ouargla, 2011. Statistics of date production in the wilaya of Ouargla. Report of the Direction Des Services Agricoles de Ouargla.
DSA of Ouargla, 2015. Statistics of date production in the wilaya of Ouargla. Report of the Direction Des Services Agricoles de Ouargla.

Eyzaguirre B., 2005. Cultural factors and plant genetic diversity. Conservation and sustainable use of agricultural biodiversity, Reference guide. International Potato Center.Users' Perspectives with agricultural research and development. Los Banos, Laguna, Philippines, Vol. 1, pp. 39-45.

Gounot M., 1969. Méthode d'étude quantitative de la végétation. Ed. Masson, 7th Edition. Paris, 314 pp.

INRAA, 2006. Second national report on the state of plant genetic resources, Institut National de la Recherche Agronomique. Algiers, $25 \mathrm{pp}$.

Kassah A., 1994. Cours spécialisé: Diagnostic rapide et stratégie de développement en milieu oasien - Etude comparative des oasis au Maghreb et dans le monde. CRDA Tozeur Tunisia and CRSTRA Algeria. Report, $28 \mathrm{pp}$.

Khemies F., 2013. Inventory of local varieties of fruit growing and their respective biotopes in the Wilaya of Tlemcen. These Magister, Département des Sciences Agronomiques et Forestières, Universite Abou Bekr Belkaid Tlemcen UABT, 221 pp.

Munier P., 1973. Le palm dattier. Maisonneuve et Larose ed., Paris, 211 pp.

WFP, 2007. Map National Monitoring Report on the State of Phylogenetic Resources for Food and Agriculture, $32 \mathrm{pp}$.

Rouvillois- Brigol M., 1975. The country of Ouargla. Variations and organization of a rural space in a desert environment. Département Géographie Université, Paris, 389 pp.

Shannon C.E. \& Weiner W., 1949. The mathematical theory of communication. Univ. Illinois Press, Urbana, Chicago III, 125 pp.

Simpson E.H., 1949. Measurement of Diversity. Nature, 163,688 . http://dx.doi.org/10.1038/163688a0

Tirichine A., Belguedj M., Benkhalifa A. \& Guerradi M., 2011. Rehabilitation of knowledge and know-how in date palm (Phoenix dactylifera L.) genetic resources management. Knowledge Management for Development Journal, 7: 188-193. 
